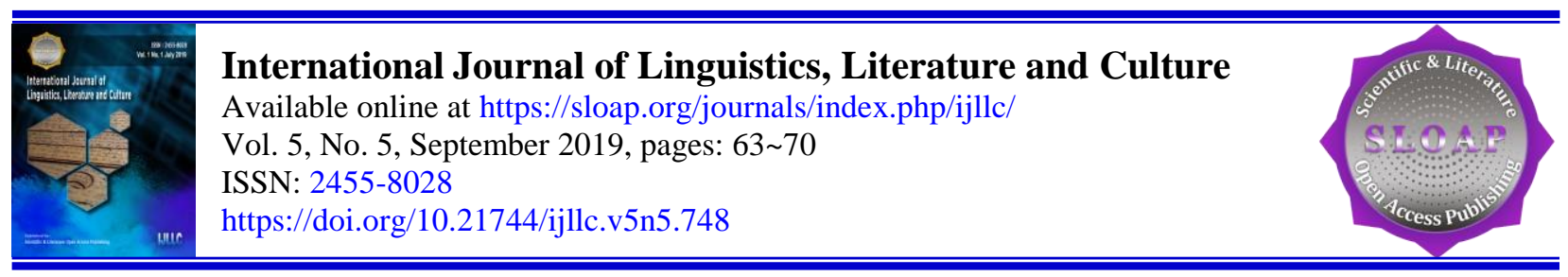

\title{
Projection Clauses Application on Pan Balang Tamak Text
}

\author{
I Ketut Suardana ${ }^{\text {a }}$ \\ I Nengah Sudipa ${ }^{b}$ \\ I Nyoman Sedeng ${ }^{c}$ \\ Putu Sutama ${ }^{d}$
}

Article history:

Received: 09 March 2019

Accepted: 31 July 2019

Published: 18 September 2019

\section{Keywords:}

grammatical metaphore; pan balang tamak text; preposition meaning; projection clause; proposal meaning;

\begin{abstract}
Pan Balang Tamak text is one of popular texts in the community of BaliIndonesia. Since several years ago, the popularity of the text has declined in community. Even more, many Balinese young generations do not recognize the text at all. The related institutions do some efforts to prevent the text from extinction, one of which is to write spoken text into written text. Many versions of Pan Balang Tamak written text are found in community, one of which is Pan Balang Tamak written. The text is viewed as contradiction from the figure's character point of view. Language has very important role to identify the character of the figure through social interaction. The language used in social interaction is projection clauses. The research aims to find out the appropriate figure's character through projection clauses. The theory used to analyze the projection clauses is the theory of projection clauses. The method used for this research is qualitative by describing the result of the research. The technique used to collect the data is Pilah, the technique organizes the clause structures and modality systems. The finding of the research is: (i) Jero Klian uses minor clause, imperative and declarative in proposal meaning, (ii) Pan Balang Tamak uses mayor clauses, grammatical metaphor, declarative in proposition meaning.
\end{abstract}

2455-8028 ${ }^{\circledR}$ Copyright 2019. The Author. This is an open-access article under the CC BY-SA license (https://creativecommons.org/licenses/by-sa/4.0/) All rights reserved.

\section{Author correspondence:}

I Ketut Suardana,

Bali Dwipa University, Denpasar, Bali

Email address: suardanate920@gmail.com

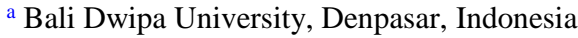

${ }^{\mathrm{b}}$ Udayana University, Denpasar, Indonesia

${ }^{c}$ Udayana University, Denpasar, Indonesia

${ }^{\mathrm{d}}$ Udayana University, Denpasar, Indonesia
} 


\section{Introduction}

Text Pan Balang Tamak is one of Balinese text which was ever very popular in many years ago in spoken text. Unfortunately, the popularity of the text has declined since several years ago. Even more many Balinese young generations do not recognize the text. The phenomenon triggers the stakeholders or the related institutions to anticipate from the extinction of the text. Many efforts have been done to survive the existence of the text, one of which is to write the spoken text into written text. The text has been written in many versions with their own language styles. One of the popular written text is Satua Pan Balang Tamak written by Supatra (2006).

The existence of the text in community is considered being contradictive from Pan Balang Tamak character point of view. There are some perceptions living in community regarding to the text, namely: (i). First, the text is viewed as historical text that Pan Balang Tamak ever lived in Bali and gave much contribution for Balinese people. This perception is built by the existence of pelinggih for Pan Balang Tamak found in several villages located in Bali. Pelinggih is temple where Hindu people pray for the God. (ii). The text is considered as an imaginative text, Pan Balang Tamak has good character in the text. The character is used to become life guidance. (iii). The text is an ordinary narrative text, Pan Balang Tamak has bad character in the text. the character should not be imitated in community. (iv). An ordinary text, Pan Balang Tamak has good and bad characters in community (Yani et al., 2018; Ekasani, 2016).

These phenomena trigger the writers to find out Pan Balang Tamak and Jero Klian characters as main figures in the text. The embedded characters in the figures can be seen from language usages as how language is spoken by the figures involved in the text. The text involves two main figures, namely: Jero Klian and Pan Balang Tamak. Jero Klian serves as the head of a village, while Pan Balang Tamak serves as a commoner in the text. Again, language is one of indicators to define one's character in the text. The language usage can be detected through language uttered in social interaction in which involve clauses serving as meta-functions such as ideational, interpersonal and textual meaning (Halliday \& Hassan, 1989).

Those functions of language are used in social interaction in once. Language serving as experiential meaning is called ideational meaning. Language serving as exchange is called interpersonal meaning. Language serving as organization for message is called textual meaning. Those functions cannot be in a part from functions to others, they work together to create context of situation within a text. Those functions of language are found in Pan Balang Tamak text. One of the significant verb usages creating context of situation is projection verb. Projection verbs are verbs related to verbal and mental processes (Halliday et al., 2014). The usage of projection verbs suggests the relationship Pan Balang Tamak and Jero Klian.

From this phenomenon, this article focuses on how the projection verbs realized through clauses are employed in the text (Zobl, 1983; Baker, 1989; Grimshaw, 1997; Chen, 2016). This research can identify the character of each figures in the text. The theory used to analyze the projection verbs (further on is called projection clause) is the theory of clause complex proposed by Halliday et al., (2014).

\section{Materials and Methods}

This research uses the theory of projection clause in Systemic Functional Linguistics (SFL) perspective. As mentioned above, projection clauses are related to clauses employing verbs belonging to verbal and mental processes. However, not all mental process can be used as projection clause. Mental process related to cognition and desideration verbs can be used as projection clause. Cognition verbs are like: know, think, believe, trust, understand, comprehend and others. Desideration verbs refer to verbs related to expectation such as hope, wish, require, need, want and others.

All verbal processes can be used as projection clause. According to Halliday \& Christian (2004), there are two types of process serving as verbal process as below.

Table 1

Verbal process type

\begin{tabular}{lll}
\hline Type & & Example of verbs \\
\hline Activity & Targeting & praise, insult, abuse, slander, flatter, blame, chide \\
& Talking & speak, talk
\end{tabular}




\begin{tabular}{lll} 
Semiosis & $\begin{array}{l}\text { (Neutral quoting) } \\
\text { Indicating }\end{array}$ & $\begin{array}{l}\text { say, tell } \\
\text { tell (somebody that), report, announce, notify, argue, } \\
\text { persuade, promise } \\
\text { tell to do, ask somebody do, order, command, persuade } \\
\text { Imperating }\end{array}$ \\
& somebody do, convince somebody do, \\
\hline
\end{tabular}

Table of verbal process type (Halliday et al., 2014)

According to Halliday et al., (2014), the analysis of projection clause involves three aspects, namely: (a) the level of projection, (b) the mode of projection and (c) the speech function.

a) The level of projection refers to the content of the projected clause, whether it is realized by mental process or verbal process. Mental process projects the clause in the form of "idea". Verbal process projects the clause in the form of "locution".

b) The mode of projection refers to the status of interdependency of the clause whether paratactic or hypotactic. Paratactic is related to direct speech (called quote), the projecting and the projected clauses are "equal. The hypotactic is related to indirect speech (called report), the projecting and the projected clauses are "unequal".

c) The speech function does not only refer to proposal and proposition meaning but also focuses on minor speech functions such as greeting and exclamation.

Proposal is speech function serving as command or offer, (i) degree of obligation such as allow to, supposed to, required to (ii) in an offer, degree of inclination. The such aspects is called modulation Clauses employing obligation proposal is often used be persons who have higher status in community to communicate to lower status persons.

Proposition is speech function, related to "yes" or "no" statement, called modalization. The scope of proposition (i) degree of possibility and (ii) degree of usuality. Both aspects can be released by finite modal operator (will) and modal adjunct (possibility and usuality).

This research uses qualitative method, describes the analysis of the projection clauses based on the theory of clause complex from SFL. The data analyzed in this research is Pan Balang Tamak text (Supatra, 2006). The text is written text in Balinese language. There are three reasons why the text is used as the data: (a) The text uses setting Balinese nuance associated to Balinese social life. Linguistically, the language used in the matches with the setting of the text. (b) The text employs projection verbs that change the context of situation. (c) The text contains deep social semiotic value released through projection clauses.

The data source is from all of the clauses employed in the text (Supatra, 2006). The clauses employ projection verbs are collected based on the process, status and speech function. The technique used to identify the data is Teknik pilah (Sudaryanto, 2015), the technique classifies elements of the clauses which lead to certain meaning. The data are analyzed based on the theory of projection clause. The data are written in two languages, Balinese and English. The results are described descriptively in English.

\section{Results and Discussions}

As mention above, the text contains very deep moral value in which involves two main figures. Pan Balang Tamak is a commoner in a village who is hated by Jero Klian and other commoners. Pan Balang Tamak has high intelligence to detect everything addressed to him. Jero Klian and other commoners feel disturbed to run their activities in the vallage. Because of that reason, Jero Klian and other commoners want to trap Pan Balang Tamak by various ways. Jero klian serves as the village leader, always abuse the authority as a leader to accelerate what he wants. The abuse done by Jero Klian can be seen from the clause point of view. Here are number of clauses applying projection clauses as below.

Text 1

Klian banjaré suba mapangarah apang krama banjaré pesu semeng-semeng rikala siapé suba pada tuun.

The head of banjar inform to all commoners leave the house at the time when the chicken turns down from the nest.

The verb inform belongs to verbal process, the target is all commoners to do what the leader inform. The verb inform indicates that the requirement to leave the house is only desire of the leader. The commoners do not have to

Suardana, I. K., Sudipa, I. N., Sedeng, I. N., \& Sutama, P. (2019). Projection clauses application on pan balang tamak text. International Journal of Linguistics, Literature and Culture, 5(5), 63-70. https://doi.org/10.21744/ijllc.v5n5.748 
follow what he needs. In other word, the head of banjar does not have right to fine the commoners who do not follow the information. The projected clause is proposal with low rank because linguistically, there is no reason which will be used as punishment.

Text II

Klian banjar "Pan Balang Tamak, sawiréh sing milu ngalih kayu jani lakar kena danda".

Pan Balang Tamak "mangkin dumun. Dados tiyang kena danda, saentukan tiyang ngayah sekadi arah-arahan Jero Klian".

Kliané banjar "sawiréh bapa Balang Tamak tusing nuutin awig-awig banjar, ento mawinan Bapa keni danda".

Pan Balang Tamak "Sira nénten ngamiletan. Tiyang sampun ngemargiang arah-arahan banjaré, mangda medal rikala siapé suba pada tuun. Tiyang daweg nika sampun bangun sakéwala siap tiyangé nénten tuun-tuun uli bembengané. Sawiréh dugasé ento siap tiangé sedeng makeem. Sampun raris tengai wawu siap tiyangé tuun. Wawu lantas tiyang ke jaba, dong dapetang tiyang kramané sami sampun makta kayu. Napiké tiyang iwang asapunika?",

Jero Klian : :Pan Balang Tamak, because you did not involve to take log, you will be fined".

Pan Balang Tamak : "Wait moment, why am I fined, because I had done based on what you instructed".

Jero Klian : "Because you did not follow the regulation, that is the reason why you will be fined".

Pan Balang Tamak : "Who broke the regulation, I follow your instruction to do ngayah at the time when chicken turn down from the nest. In that time, I already got up but unfortunately, my hen did not turn down from the nest. It was midday my hen turned down from the nest then I went out. I found many commoners bringing logs. Do I make mistake?

The social interaction involving Jero Klian and Pan Balang Tamak above can be analysed as follow:

Klian banjar "Pan Balang Tamak, sawiréh sing milu ngalih kayu jani lakar kena danda".

Jero Klian : "Pan Balang Tamak, because you did not involve taking log, you will be fined".

1) The leader of the village uses minor clause Pan Balang Tamak, the clause is called calls functioning to keep Pan Balang Tamak's attention. The leader only speaks to Pan Balang Tamak.

2) The leader focuses on the mistake done by Pan Balang Tamak by uttering circumstance of cause as Theme. The leader uses the clause as Theme because the leader wants to blame Pan Balang Tamak.

3) The clause jani lakar kena danda (you will be fined) employes modality operator lakar indicates that the leader shows up the superiority to Pan Balang Tamak. The leader has right to fine everybody who has different mind from the leader.

4) The projected clause contain proposal meaning because the leader ask Pan Balang Tamak to pay the fine.

Pan Balang Tamak "mangkin dumun. Dados tiyang kena danda, saentukan tiyang ngayah sekadi arah-arahan Jero Klian”.

Pan Balang Tamak : "Wait moment, why am I fined, because I had done based on what you instructed".

The clauses above can be analysed as follow:

1) The clause wait moment is congruent with I do not agree. The clause used by Pan Balang Tamak is called grammatical metaphor (Halliday, 1994) functioning deny what the leader stipulated to Pan Balang Tamak. The clause is used to minimize the leader get disappointed. The denial is uttered with the polite way.

2) The clause dados tiyang keni danda is interrogative form, but the function is to emphasise or review what the leader stipulated. The clause does need "yes" or "no" answer. Pan Balang Tamak shows his identity as commoner, he can not be blamed to have mistake without any proof.

3) The clause seantukan tiyang ngayah sekadi arah-arahan Jero Klian is circumstance reason clause functioning as proof that Pan Balang Tamak is good commoner who always runs the duty well. This clause is related to high usuality so the clause has proposition meaning.

Kliané banjar "sawiréh bapa Balang Tamak tusing nuutin awig-awig banjar, ento mawinan Bapa keni danda”. Jero Klian : "Because you did not follow the regulation, that is the reason why you will be fined". 
The clause uttered by Jero Klian above can be analysed as follow

1) The leader uses circumstance of reason as Theme, he emphasises the reason why Pan Balang Tamak is vharged fine. The leader only focuses on how to trap Pan Balang Tamak in order the leader can fine Pan Balang Tamak.

2) The clause ento mawinan Bapa keni danda indicates that the leader uses his authorities to stipulate what he wants to Pan Balang Tamak.

3) The clause is declarative form, but the meaning is command to pay the fine. In other word, Pan Balang Tamak is supposed to pay. It belongs to proposal.

\section{Pan Balang Tamak "Sira nénten ngamiletan. Tiyang sampun ngemargiang arah-arahan banjaré, mangda medal rikala siapé suba pada tuun. Tiyang daweg nika sampun bangun sakéwala siap tiyangé nénten tuun-tuun uli bembengané. Sawiréh dugasé ento siap tiangé sedeng makeem. Sampun raris tengai wawu siap tiyangé tuun. Wawu lantas tiyang ke jaba, dong dapetang tiyang kramané sami sampun makta kayu. Napiké tiyang iwang asapunika?"}

Pan Balang Tamak : "Who broke the regulation, I follow your instruction to do ngayah at the time when chicken turn down from the nest. In that time, I already got up, but unfortunately, my hen did not turn down from the nest. It was midday my hen turned down from the nest then I went out. I found many commoners bringing logs. Do I make mistake?"

Pan Balang Tamak disagree to the leader stipulation regarding to punishment, he uses the clause in interrogative form functioning as denial. He needs some proof that the mistake was done by Pan Balang Tamak The following clauses functions as proof tha Pan Balang Tamak is good commoner who run the regulation well.

The clause napikê tiyang iwang asmpunika is interrogative form functioning as proof that Pan Balang Tamak did something based on the leader's instruction. The clause does not need "yes" or "no "answer, but it needs consideration that Pan Balang Tamak does not deserve to get fined.

\section{Text III}

Kenehné krama banjaré masih lakar nyekin Pan Balang Tamak apang taén bakat kencanin tur kena denda.

The commoners want to trap Pan Balang Tamak in order Pan Balang Tamak get punishment and get fined.

This clause hires mental process released with kenehne (want), the clause is projection of mental process. The projected clause is an idea to trap Pan Balang Tamak. The projected clause has proposition meaning because the idea proposed by the commoners can come true or not since the idea is desire supported by perception.

\section{Text IV}

Jero mangku makeneh "sinah suba né paican Ida Betara tekén damuh-damuh duwéné sami”.

The leader of ceremony thinks" It is probably God/s blessing for the commoners"

The clause above is mental projection clause released with cognitive mental process. The projected clause is an idea, related to belief of the leader based on what he views. The lexes probability indicates the ceremony leader has strong belief of what he views in front of him. The adjunct functions as modalization indicating belief because what he finds is located in temple. Everything found in temple is God blessing and commoners must thank to the God.

\section{Text V}

Pan Balang Tamak maan pengarah "uling buin mani, tusing dadi macelep ke pekarangan timpal, tur nyemak gelah anak lénan, yen sing tau ané ngelahang. Nyén ia ketara macelep tur nyemak gelah anak len, lakar kene danda".

Pan Balang Tamak gets instruction "start from tomorrow, no one can enter one's land, take one's entity without any promise from the owner. For who is seen to enter and take entity in one's land will be fined".

Suardana, I. K., Sudipa, I. N., Sedeng, I. N., \& Sutama, P. (2019). Projection clauses application on pan balang tamak text. International Journal of Linguistics, Literature and Culture, 5(5), 63-70. 
Semantically, the utterance applies verbal process, the initiator is the leader of village because he established the regulation. The regulation serves as medium to control the commoners in the village. The projectcted clause is imperative clause released with uling buin mani, tusing dadi macelep ke pekarangan timpal, tur nyemak gelah anak lénan yen sing tau ané ngelahang. The projected clause suggests that prohibition must be followed by all commoners. The clause nyén ia ketara macelep tur nyemak gelah anak len lakar kene danda serves as punishment for who break the role. The clause is declarative form functioning to remind the commoners not to break the regulation. The modality lakar is used in the regulation, it indicates that the regulation has higher position than the commoners. The projected clause has proposal meaning because the regulation is written to control the commoners and the commoners are supposed to follow the instruction.

\section{Text VI}

Jero Klian lantas mamunyi "énggalang lébang cicingé Bapa, apang maboros. Yén sing keto Bapa lakar kena
danda”

The village leader says "escape your dog soon to hunt, if you cannot do, you will be fined"

The projection clause above is paratactic using verbal process, the projected clause uses two clause complexes. The first clause complex is hypotactic suggesting purpose and the second one is hypotactic suggesting contingency. The first clause complex is imperative as the main clause. The leader asks Pan Balang Tamak to escape his dog. This clause can be used by the person who has right to ask to lower position in community. The second clause suggests threatening if the receiver does not escape the dog. The cause suggests that the leader shows up the superiority in front of Pan Balang Tamak.

The leader uses modality lakar, the leader shows himself that he is decision maker for all commoners in the village. If Pan Balang Tamak does not obey to the leader, fine will be charged to him.

\section{Conclusion}

Based on the research, the text employs two kinds of process, mental and verbal processes in both paratactic and hypotactic. The projection clause uttered by Pan Balang Tamak is verbal process. The projected clause uses mayor clause, modulation or proposition, grammatical metaphor in interpersonal. The leader of the village uses verbal process; the projected clause uses minor clause. The leader uses circumstance of reason as Theme in the clause to blame Pan Balang Tamak. Those projection clauses are proposal.

Mental projection clauses are employed in the text, namely desideration and cognition verbs. Desideration verb is hypotactic projection clause; the projected clause suggests an idea. Cognition verb is stated in paratactic projection clause. The projected clause is declarative form functioning to express the speaker's idea.

\section{Conflict of interest statement}

The authors declared that they have no competing interest.

Statement of authorship

The authors have a responsibility for the conception and design of the study. The authors have approved the final article.

\section{Acknowledgments}

This work was self-fund research. 


\section{References}

Baker, M. C. (1989). Object sharing and projection in serial verb constructions. Linguistic inquiry, 20(4), 513-553.

Chen, S. K. (2016). Circumstantiation of projection: Functional syntax of angle in English and Chinese. Ampersand, 3, 71-82. https://doi.org/10.1016/j.amper.2016.05.002

Ekasani, K. A. (2016). The analysis of english - indonesian exclamative clauses in the novel entitled the adventures of tom sawyer by mark twain and their indonesian version entitled petualangan tom sawyer translated by djokolelono. International Journal of Linguistics, Literature and Culture, 2(1), 16-28.

Grimshaw, J. (1997). Projection, heads, and optimality. Linguistic inquiry, 373-422.

Halliday, M. A. K \& Matthiessen, Christian MIM (2004). An Introduction to Functional Grammar, 3.

Halliday, M. A. K., \& Hasan, R. (1989). Language, context, and text: Aspects of language in a social-semiotic perspective.

Halliday, M. A. K., Matthiessen, C., \& Halliday, M. (2014). An introduction to functional grammar. Routledge.

Sudaryanto, D. P. (2015). Metode dan aneka teknik analisis Bahasa [Method and technique of language study].

Supatra, I.N.K. 2006. Satwa Bali Pan Balang Tamak. Denpasar: CV. Kayumas Agung.

Yani, L., Artawa, K., Satyawati, N. M. S., \& Udayana, I. N. (2018). Transitivity construction of verbal clause in Ciacia language. International Journal of Linguistics, Literature and Culture, 4(3), 15-23.

Zobl, H. (1983). Markedness and the projection problem. Language learning, 33(3), $293-313$. https://doi.org/10.1111/j.1467-1770.1983.tb00543.x

Suardana, I. K., Sudipa, I. N., Sedeng, I. N., \& Sutama, P. (2019). Projection clauses application on pan balang tamak text. International Journal of Linguistics, Literature and Culture, 5(5), 63-70. https://doi.org/10.21744/ijllc.v5n5.748 


\section{Biography of Authors}

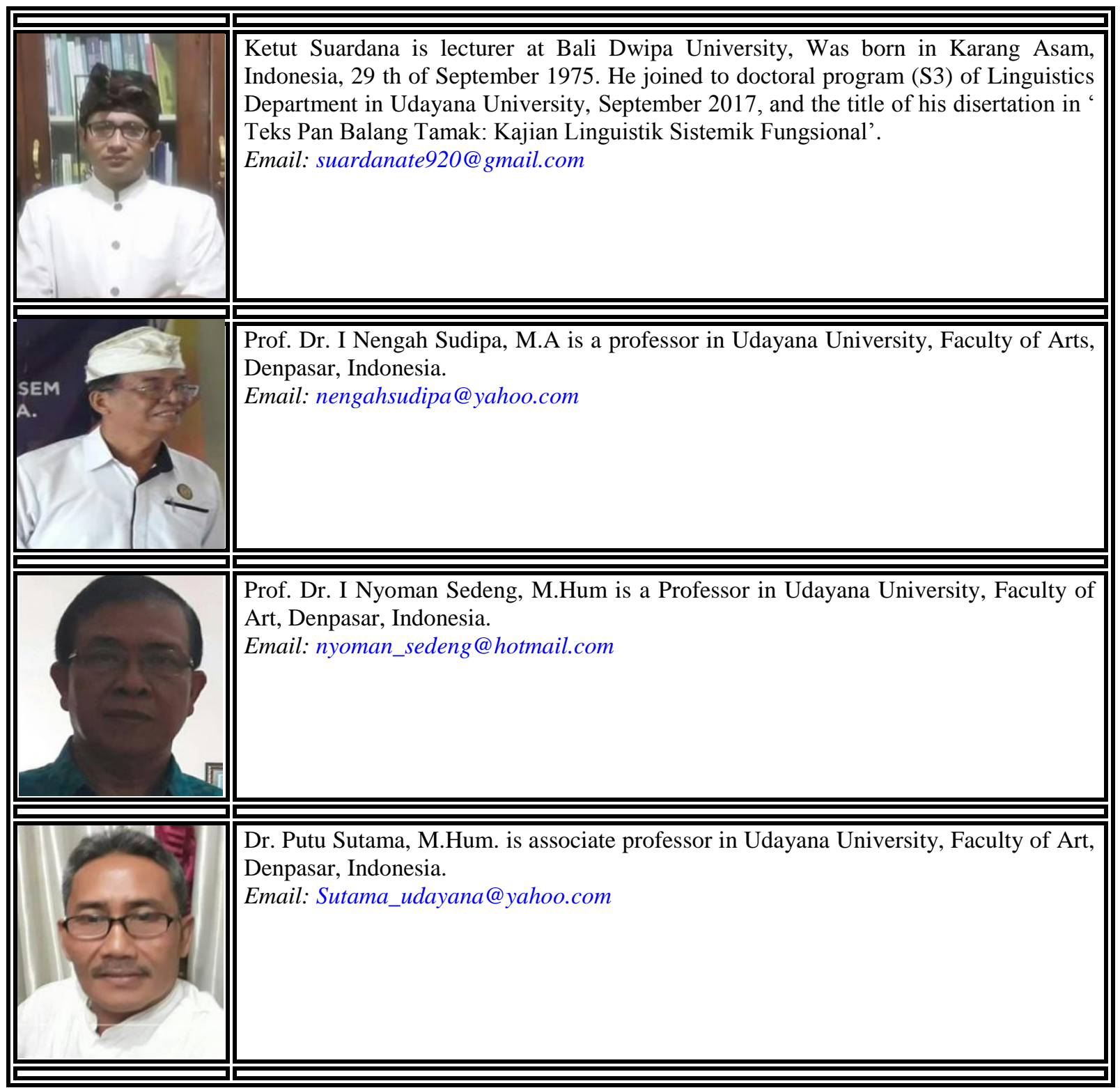

